\title{
6. Random Thoughts of an Occasional Practitioner
}

\author{
Deryck Scarr
}

Like many other contributors to this volume, I came to life writing quite by chance and I hesitate to add reflections that touch upon theory in any shape or form, unless in argument against paying overmuch attention to psychological analysis even of the living let alone of the dead. The authorities who deal in psychology were once likened to 'Romans consulting Sibylline books', but admittedly by a novelist in wartime. ${ }^{1}$ And while I have always greatly admired works like Carola Oman's Life of Nelson, I had never particularly seen myself as setting up as a biographer in any major way, and had not much more idea of it than that the subject should be central and have left a sufficient direct record to be able to speak up for him or herself to a considerable degree.

If I had gone ahead with a history of sixteenth-century Plymouth at the Institute of Historical Research in London, as envisaged during my final months as an undergraduate in England, instead of venturing, via the Research School of Pacific Studies, into the South Seas when I graduated and becoming entrapped by tropical islands, Francis Drake and John Hawkins would presumably have made appearances as sea dogs ashore but perhaps not much more.

The first thing of any size that I ever did - a study of the Western Pacific High Commission (WPHC) based on archives admirably housed at that time in seductive Fiji - was actually rather criticised by an examiner for lacking biographies.

As a considerably expanded doctoral thesis, it was probably a big enough book as it stood and, by way of exemplifying the perversity of these things, a senior scholar then of these ANU halls found it seriously improper for me to have said of Sir John Gorrie, then the Chief Judicial Commissioner to the WPHC, that '[i]n his desire to see the law amended to what he considered it should be, he was invariably confused as to what it actually was' ${ }^{2}$ In further contrast, the Deputy British Resident Commissioner of the New Hebrides in those days found this comment very much to his taste when he read the original thesis, perhaps because administrators are often at loggerheads with lawyers, and, to the benefit

1 M. Davie (ed.), The Diaries of Evelyn Waugh (London 1995), 544.

2 D. Scarr, Fragments of Empire: a History of the Western Pacific High Commission 1877-1914 (Canberra 1967), 43. 
of the ensuing book, he opened up the Condominium Joint Court archives in Vila. Later, as Governor of Seychelles, Sir Colin Allan suggested I write a history of Seychelles. As it eventuated, this was not at all to the joy of the revolutionary government coming far from bloodlessly into power between my two long visits in 1976-7; but the book does in fact have a few outline portraits of its own: named slaves from the late eighteenth century onward; estate- and slave-owners documented from the notaries' extensive archives for generations since the 1770s; and a post-World War II Chief Justice from Britain who presided in court in Port Victoria wearing nothing but wig and gown on the bench because, after all, it can be so warm in Seychelles. ${ }^{3}$

Major figures leaving substantial records may very well impose themselves upon even an initially reluctant biographer. While I was working in the WPHC archives with Fiji all around, this happened in the case of the European whose portrait - which was signed with his Fijian nickname $\mathrm{K}^{\prime} \mathrm{oi} \mathrm{Au}$, Na Kena Vai, meaning 'I, the Very Bayonet', according to exceptionally sound Fijian opinion - was, to my knowledge, the only one hanging in the office of the Secretary for Fijian Affairs in Suva when that post was held by a Fijian.

The WPHC was, after all, set up to avoid the necessity of further direct responsibilities being assumed by Britain in the Pacific after the Cession of Fiji in 1874-5. And his major appearances in WPHC record quite apart, this unusual Vavalagi had already turned up in Foreign Office correspondence when, as Acting British Consul at Levuka in the mid to late 1860s, he was, among much else, doing his utmost to prevent speculators on the scale of the Polynesia Company of Melbourne from acquiring doubtful title to vast areas of land in Fiji. He came very much to the fore again in the records of the Cakobau Government as its inspirational Chief Secretary in the early 1870s. And you can hardly fail to recognise his style in the Fiji press of those very fraught years when editorials in the rival newspaper to the settlers' much-preferred Fiji Times declared:

What is wanted by a certain class of men is an Utopia of rampant Anglo-Saxons, with a subject population of Fijians (among them, in proportion as 70 to 1 ) - among whom to live, and among whom to find, or make, hewers of wood and drawers of water - to be regarded as the ancient Phoenician regarded the Iberian, - or the modern Spaniard 
the aborigines of Hayti; and, in due time, as these countries, and more modern and neighbouring ones have done - to furnish forth its perfect Iliad of woes. ${ }^{4}$

For settlers, after all, had been announcing that his government's

line of policy has been a systematic attempt to demonstrate the possibility of placing the superior race in a utter subserviency to the inferior one; but we being men of Anglo Saxon descent are unwilling and determined not to be a medium for the solution of such a problem. ${ }^{5}$

As he put it, their desire was

[t]o reduce the Kingdom of Fiji to the position of a British Colony, and to subject its Sovereign, Chiefs, and people to some such status as that of the aboriginal races of other countries which have been thus 'annexed' and subjected. ${ }^{6}$

And then from 1875 until his death in 1897 at 61 he is never out of the enormously rich record of colonial Fiji.

This was J.B. Thurston - Sir John, eventually - London-born, Jersey-residing as a young boy, a merchant seaman from the age of 13, castaway on Rotuma during a plant-hunting trip at 25, planter and labour-recruiter. He was the right arm of King Cakobau's Government before he became Colonial Secretary after the conditional cession of the islands, and then Governor of Fiji as well as High Commissioner and Consul-General for the Western Pacific - a founder of the Fijian Administration and the Native Tax System which put money into Fijian hands through the refunds paid after the tax assessments were met; unchanging in his belief in a serious degree of Fijian autonomy; unlikely to have allowed the indentured Indian population to rise beyond the 18,000 it had reached by 1897 when he died; a demolisher of the argument that Fijians were inevitably doomed to die out; and an inveterate prolific private as well as official correspondent about pretty well everything in the Southwest Pacific. Robert Louis Stevenson was put rather sharply in his place when his interference in Samoan politics came under the High Commissioner's eye, but the eventual olive branch from the Apia-residing novelist was well received.

\footnotetext{
4 Fiji Gazette, 5 November 1873; and quoted D. Scarr, The Majesty of Colour: a Life of Sir John Bates Thurston: Volume One: I, the Very Bayonet (Canberra 1973), 206.

5 Encl. Stirling to Admiralty 18 April 1873, British National Archives: Adm. 1/6261 and quoted Scarr, Bayonet, 223.

6 Fiji Gazette, 30 August 1873; Scarr, Bayonet, 206.
} 
Yet very little was known of J.B. Thurston's background, nor a great deal in detailed context either, and it was great fun to track all this down in the Fiji archives, the Public Record Office in London, and in widely spread private letters and occasional journals around the world. Commonly, his tone was sardonic and his arguments well founded. As he asked a fellow Commissioner to Samoa, the American G.H. Bates, to tell Mrs Bates in 1889,

not only does the American Government senselessly block my way in putting down robbery - murder \& all abominations though it practically has no trading interests in the Western Pacific - but contrary to the Statute at Large, English built vessels cruise about here under American colours nominally owned by Americans -or soi-disant Americans, in order to evade the jurisdiction of the British High Cmmr. Just now when the Sovereign people are warm upon the subject of their 'Duties in Samoa' they might take up the wider question of their Duty in the Western Pacific. ${ }^{7}$

Thurston kept no private press-copy letter-book and for this jibe you have to search the George Hardy Bates Papers at the University of New Delaware.

For much else there are the archives at Kew Gardens and the Aborigines Protection Society, among other places, because the amateur botanist commented on politics and the Aborigines Protection Society needed protection from successors to supposed philanthropists like the merchant William MacArthur, who had possessed its ear in pressing for Fiji's annexation in settlers' interests during the 1870s. But the official record itself is vast, of course, and the manner there is very often unofficial too. Again, you place these private communications and the letters Thurston wrote to his sisters alongside the official dispatches and minutes and you check to see whether they add up. Are they consistent?

They always are - and when the established yet still controversial head of a colonial administration declares in a minute for his juniors that 'one half of the young maramas who are sometimes supposed to be guilty of indiscretions with young fellows in the evening, simply get into obscure corners in order to enjoy the luxury of a smoke', because the Methodist Church banned tobacco, you may continue to be intrigued. ${ }^{8}$

Thurston possessed genuine personal ties in Fiji and when, among much else, I asked his eldest daughter and last surviving child - then in her early 80s but aged 12 when he died - whether she remembered Ratu Josefa Lalabalavu, son of the Tui Cakau of the 1860s and 1870s and holder of this title himself, she immediately replied: 'Of course - my father's adopted son.'

7 D. Scarr, Viceroy of the Pacific: the Majesty of Colour: a Life of Sir John Bates Thurston (Canberra 1980), 263. 8 National Archives of Fiji: Colonial Secretary's Office: CSO93/2765; Scarr, Viceroy of the Pacific, 209. 
So this biography really rather imposed itself with the Pacific background as well as the central subject leaping from the written record, but nothing on similar lines was planned. There were other things to work on, the study of Seychelles from human settlement around 1770 onward at the Governor's invitation among them; and I was away in or in search of Seychelles when, having read the Thurston biography's first volume, with its culminating point at Cession in 1874-5, a committee in Fiji asked if I would do its long-considered biography of Ratu Sir Lala Sukuna.

That could have been a pretty startling prospect as it would be the more-or-less official life of a high chief born in 1888, a decorated and wounded World War I French Foreign Legionnaire, an Oxford graduate, a barrister of the Inns of Court in London, a major recruiter of Fijian servicemen in the World War II, the first Fijian Secretary for Fijian Affairs, principal spokesman for the Fijian people for about 30 years until his death in 1958, and a man closely related to the chairman of the biography committee, Ratu Sir Kamisese Mara, at that time the Prime Minister. Ratu Sir Lala Sukuna was Ratu Mara's great-uncle and, it was generally thought or assumed, had been very much his mentor in youth and early manhood.

A prospect to baulk at, perhaps, although, after months in Seychelles, I was accustomed to free access to records and people. In fact, the revolutionary post-coup government actually rather congratulated me by taking exception to my simple narration of inconvenient fact and managed to frighten off publishers for two decades.

But of Ratu Mara's sophistication I had not the least doubt. Obviously he had been the up-and-coming man since I was first in Fiji on a series of long visits from 1962, initially not working primarily on Fiji at all but surrounded by it. And, while naturally keeping very quiet, having absolutely nothing to contribute anyway, I had a reasonable number of contacts as well as at least one very good friend who knew him well. Whatever reservations I had gathered there about Ratu Mara's thin skin and uncertain temper, I had never heard that if he asked you to do a job he did not leave you alone to do it with all the help he could give.

In fact, I found him entirely supportive and non-interfering. Nor as a whole was the committee other than unobtrusive and helpful. The word went out that I was to be well received wherever I turned up around the country, with or without an accompanying matanivanua, although usually with someone from the region in question - and stories such as Ratu Sukuna's miraculous ability to be in two or more places at the same time flowed. 
Mere conceit, perhaps, had prevented me from supposing that anyone in the world would imagine they could make me or indeed would want a tool for such a project anyway, and an ardently Ratu Sukuna-admiring committee member eager to take on the biography himself had been suppressed. Other members rather enjoyed making sure of this, I thought. The committee's secretary, Dr Isireli Lasaqa, then Secretary to Prime Minister and Cabinet, was an ANU $\mathrm{PhD}$ graduate in geography and we knew each other well; and I not only noticed Ratu Mara observing a mild exchange or two between me and the aspiring committee member with amusement, but I also found him frank and open in private conversation about how he and Ratu Sukuna had related during Ratu Mara's rebellious days as an undergraduate and District Officer. Medicine, not administration-cum-politics, had been Ratu Mara's strongly preferred career; he had resented Ratu Sir Lala's insistence on his giving up medical studies in Dunedin for Modern History at Oxford, and he sometimes regretted having given in.

A great power's ambassador was once kept waiting for half an hour while we talked - and nothing Ratu Mara said was declared to be private, even though, in light of the general public perceptions about his relationship with Ratu Sukuna, some clearly could have been.

In other contexts, Mahatma Gandhi's emissary to Fiji of the late 1920s, S.B. Patel, lawyer and long-time quiet political eminence in Fiji, provided illuminating comments as a non-attending committee member. In the past he had rather mocked Ratu Sukuna's pronounced Britishness - the voice, the attachment to the Crown, the implicit determination that Fiji should not pass into the hands of people whose forebears had been in the islands for so short a time and whose betters, as Ratu Sukuna once put it in an uncommon moment of open exasperation, were not making a particularly good job of governing the subcontinent of India itself. As he had said, both echoing and speaking for his own people, the British Government was primarily there to look after the interests of Fijians anyway - but others' interests were also to be protected.

Ratu Sukuna invariably passed for a conservative leader and so in fact he was. As a District Commissioner in the 1930s, he was obliged to keep a detailed official diary, and I could only bless the central government's insistence on it. According to him, the semi-autonomous Fijian Administration, which had effectively died with Sir John Thurston, still provided the model. And individual Fijian families on farms of their own might be all very well in theory, but the relative isolation was very hard on wives. Village-based production under provincial control always struck him as the better plan anyway. Quite often it worked, but not invariably. Men of hereditary rank were reckoned the 'natural leaders of society' and may often still remain so in the people's eyes - but rank, he himself had always told his peers, was not an ornament. In fact, the man he appointed 
over Tailevu, long regarded as the leading province of Fiji, was Joeli Ravai - a conspicuous member of Viti Cauravou or the Young Fiji Society, a man with no rank but of powerful personality, the schoolmaster of whom Ratu Mara said in his memoirs that 'I attribute to my time under him much of my ability to face hardship and difficulty'. ${ }^{9}$ And as Ratu Sir Lala told the Legislative Council in 1947, while regretting that, for instance, there was so little real eagerness for multiracial education: 'Frankly, Fijians fear Indianisation and for this reason: Indians possess an ancient culture of which they are justly proud and from which they have no intention of departing. ${ }^{10}$

Often he was accused of confining higher education in his own society to men of rank, but in a conspicuous case his reluctance may have been based more on perception of character. In another instance, this certainly appeared in a letter to his great-nephew at Oxford in 1946, saying that, whatever Ratu Mara might think about his own role and current or future importance, people outside his own islands in Lau would not give two hoots for him until he had done something useful for them. ${ }^{11}$

As a matter of course, and with the quiet comment to me from Ratu Mara years later that he had sent Ratu Sir Lala an explanatory telegram from Oxford on the spot, this went into the volume of Ratu Sir Lala's writings that, on the heels of the biography subtitled Soldier, Statesman, Man of Two Worlds, came out with his letters from World War I battlefields, official diary extracts, minutes, annual reports on Fijian affairs, and such private correspondence as I could find. I particularly enjoyed his spoof but evidently heartfelt draft Annual Report on Fijian Affairs for 1948. It began: '1948 cannot lay claim to any spectacular achievement of policy; in fact, it can hardly lay claim to any achievement at all. ${ }^{12}$

Compliments for this volume, Fiji: The Three Legged Stool, came to the biographereditor and were duly passed on to the shade of Ratu Sir Lala Sukuna to whom they belonged; but about a dozen years after the biography's appearance in 1980 there were quiet indications that a life of Ratu Mara was rather expected of me. By then he was the President. A biography had actually been proposed by a leading National Federation Party parliamentarian in the late 1970s, but the offer had not been taken up by Ratu Sir Kamasese, as he then was, although still more usually just Ratu Mara.

9 R.S.K. Mara, The Pacific Way: A Memoir (Honolulu 1997), 15.

10 J.L.V. Sukuna, in D. Scarr (eds), Fiji: the Three Legged Stool: Selected Writings of Ratu Sir Lala Sukuna

(Suva 1983), 422.

11 Ibid., 451.

12 Ibid., 427. 
I was not at all sure how I felt about the proposition, although I had been watching him since he gave the Cession Day speech for 1962 at Levuka with, as it seemed to me, an air of disquiet about him. This I had put down to the fact that, as Commissioner Eastern and as the Tui Lau recently installed by Tongan kingmakers at Lomaloma into the bargain, he was introduced to a crowd largely of his own people by a non-Fijian, the editor of the Fiji Times. However, when the Colonial Office's archival record became available much later, it was clear that, during a year in London spent largely at the London School of Economics and Politics, but with forays into officialdom, Ratu Mara had become very well aware that the British Cabinet intended to leave Fiji as soon as a multiracial regime could be put together to inherit the independent state.

His own people's general reaction to this proposition he could easily foresee and, frankly speaking, so could any reasonably alert observer who was prepared to pay attention in the 1960s when young Fijians were quietly saying that they did not intend to end up like the Hawaiians and Maori.

Some 30 years later, when the idea of a biography came up, it was possible to make oneself very well acquainted with Britain's policy in detail. The archival resources, along with many more conversations with people at large, made a biography perfectly feasible. And, to my knowledge, Ratu Mara had not jibbed a bit about my book on the 1987 coups, not all of which I imagine he could have relished since, following the first coup, I had spent time with rebellious Taukei Movement members in the streets who did not love his concern for other people besides Fijians or, as they saw it, for his own international reputation either. When I called to see him at Government House, he was as open as ever, and again I remembered a confidential colonial assessment of about 1965 saying that he had the manner of an Oxbridge Don. An uncommonly good one, I feel obliged to say. And had he mentioned the idea, I should have agreed on all the usual generally unspoken conditions.

At the very least, it would have been interesting to be considering the career of a man who could have answered back, and perfectly feasible to have run a wellinformed late draft past him. By contrast, Ratu Sukuna was famously reserved in private as well as in public; and Thurston had been reticent with the author who produced a work that appeared after his death. ${ }^{13}$ The first Governor of Fiji, Sir Arthur Gordon, by then Lord Stanmore, had considered writing one soon after Thurston died, and it would have been fascinating; perhaps finding Lady Thurston unappreciative, he had not gone ahead with it. ${ }^{14}$

13 C. Stuart Ross, Fiji and the Western Pacific (Geelong 1909).

14 Stanmore to Arundel, 9 December 1987, J.T. Arundel Papers, National Library of Australia; Scarr, Bayonet, $\mathrm{xxx}$. 
But while Ratu Sir Kamisese Mara remained very conspicuously in harness as President of Fiji, with very delicate affairs of state still before him, the better option by far, as I thought at the time, was a volume such as the memoirs that he published in 1997. Following this, the circumstances of his leaving office in 2000 - to the glee of the Speight Gang in the captured parliament buildings but effectively at the behest of the army, which could have enabled George Speight's coup to be suppressed by negotiation if officers had acted immediately on Ratu Mara's orders as Commander-in-Chief to close off parliament so that marchers could not flow in as a human shield - did not seem to me to invite intrusion during the years before he died in 2004, when, I gathered, he was mentally as alert as ever. And I had preoccupations of my own. Actually, I regret not having made the approach, but there was a very rich archival record as well as lively memories since 1962 and some conversations from the late 1970s to help produce the biography that came out in 2008 under the title Tuimacilai.

As well as relating to a particularly boisterous stretch of sea in Lau, the province of his birth and always his place of retreat from a difficult world, this was also, after all, one of his given names; but if I had used his own or his speechwriter's image, the book could equally well have been called Man on a Tightrope, for this was what he had to be in a balancing act between rival ethnic forces for the whole of his political life.

Again, and rather more than with Ratu Sir Lala Sukuna, although not in Sir John Thurston's case where not much knowledge at all could be assumed in the majority of readers foreign to the Western Pacific, it was necessary to do a good deal more than sketch the background in order to illustrate the nature and scale of the drop lying below a political leader who was aspiring to win support from every community in the country, controversial and often misunderstood if not actually misrepresented as Ratu Mara's circumstances have sometimes been. More analysis was needed, as it was when Carola Oman wrote about Admiral Nelson, as I've lately reminded myself by reading a new edition, for she had to make and keep twentieth-century readers aware of the politics of Naples as well as the inner workings of the Royal Navy more than 200 years ago.

For Ratu Maru, one has to analyse perceptions as well as politics for decades before his birth, and it needed to be established that his perceptions were often unusual. For one thing, he did not love the mataqali as a unit of land tenure. For another, he told Ratu Sir Lala Sukuna from Oxford that 'there will be no peace of mind if we keep on underlining the differences between Indians and Fijians. Neither race seeing anything in common. One thinking the other privileged.' As a District Officer in the 1950s, he fought hard to get the colonial government's idea of multiracial local government across to all the rural communities but, 
as his official diary shows, he found Indian leaders quite as opposed to this obvious and intended nursery for future politicians at the national level as the Fijians and Europeans were. ${ }^{15}$

Later in the pre- and post-general elections, his own Alliance Party governments always had a good many more Indian votes than the opposition National Federation Party or Fiji Labour Party ever secured from Fijians, and when the voting system was rendered so opaque under the 1997 constitution it was his active support for Mahendra Chaudhry's Labour Government in 1999-2000 that put him at such risk from sections of his own people. For as he had pointed out in the pre-independence negotiations of 1969-70, with the National Federation Party pressing hard for the common electoral roll in expectation of taking government itself as a result, the cultural gulf was not an imaginary one, not least because Federation politicians confessedly had no idea how a great many indigenous Fijians thought and felt, and nor was inter-ethnic rivalry imaginary either.

'I am almost going to persuade my electors, "Let us have common roll"', Ratu Maru had said, believing in it himself in principle, 'and let us see what will happen in this country; and don't blame me because I won't be alive. ${ }^{\prime 16}$

Thirty years later, the Army deserted him, as did some of his powerful relations, and he went home to Lakeba very much wishing at times again that he had told his great-uncle to go to the devil in 1945 and stuck to medicine after all. Very bad for the country if he had done so, though, and I think that the evidence for this comes out in the biography. They might call him Pharoah, or the Towering Inferno, but it might have been difficult to get very far with the word 'dictator' before well-informed people without ending up speaking into a deep silence if not being openly challenged or laughed at.

So my ideas of a biography go not much further than the idea that the subject of it should probably open the work. Without prejudice to background and contemporaries, the subject should maintain a certain precedence throughout; and the subject again should have left a considerable personal record.

Since the lives of painters or even of novelists I admire, like Graham Greene, so far tend largely to leave me underwhelmed, biography seems, for my part, to mean becoming involved on the page with well-recorded authoritative individuals of whom all three left a significant record and one, in particular,

15 D. Scarr, Tuimacilai: a Life of Ratu Sir Kamisese Mara (Adelaide 2008), 75.

16 Ibid., 184. 
the most inaccessible in time, an amazingly extensive but scattered collection of minutes, dispatches, journals and private letters that would amusingly fill several thick volumes of their own.

Thurston received two volumes of biography in what might seem an authorial indulgence except that my condensation of the first volume in typescript, while what would then have become the second half of a single volume was being written, struck several people as being not so worthwhile when compared with the larger work from which it had been distilled. In a supporting instance, Elizabeth Longford's Wellington is likely to strike readers as exceptional unless they have read her Wellington: the Years of the Sword and Wellington: Pillar of the State of which the single volume is her expert abridgement.

My major subjects have rather chosen themselves, then, or have been suggested, and they come from the Southwestern Pacific. Yet I can imagine taking on a literate Mascareignean slave, or slave-owner, or slaving sea captain, or French privateersman of the eighteen- or nineteenth-century Indian Ocean. Harking back to school and undergraduate days, I would certainly consider Drake or Hawkins or anyone sailing with them, if more trunks of unread or half-digested documents in the subjects' own hands or from their well-attested dictation ever came to light. On the same terms, the Lord Protector Oliver Cromwell would appeal too. Yet by stretching the imagination a great deal further, and with archival understanding as well as direct knowledge of Indian Ocean islands, one might find it rewarding to take the unlettered slave Robert Sans Chagrin at his illegal arrival in Seychelles from Mozambique, where he had very different names, and to imagine if not actually trace his experiences on Silhouette and Mahé where he was known, and on any other island where he can be supposed to have lived.

Such at any rate are the passing random thoughts of an occasional practitioner. 
This text is taken from Political Life Writing in the Pacific:

Reflections on Practice, edited by Jack Corbett and Brij V. Lal, published 2015 by ANU Press, The Australian National University, Canberra, Australia. 